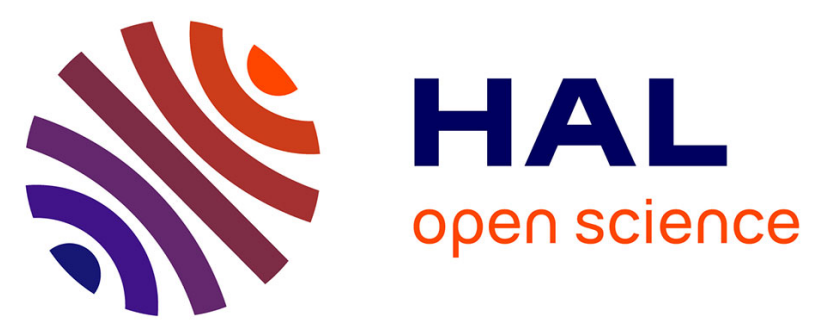

\title{
Intraadrenal Corticotropin in Bilateral Macronodular Adrenal Hyperplasia
}

Estelle Louiset, Céline Duparc, Jacques Young, Sylvie Renouf, Milène Tetsi

Nomigni, Isabelle Boutelet, Rossella Libé, Zakariae Bram, Lionel Groussin, Philippe Caron, et al.

\section{To cite this version:}

Estelle Louiset, Céline Duparc, Jacques Young, Sylvie Renouf, Milène Tetsi Nomigni, et al.. Intraadrenal Corticotropin in Bilateral Macronodular Adrenal Hyperplasia. New England Journal of Medicine, 2013, 369 (22), pp.2115 - 2125. 10.1056/NEJMoa1215245 . hal-01908272

\section{HAL Id: hal-01908272}

https://hal-normandie-univ.archives-ouvertes.fr/hal-01908272

Submitted on 30 Oct 2018

HAL is a multi-disciplinary open access archive for the deposit and dissemination of scientific research documents, whether they are published or not. The documents may come from teaching and research institutions in France or abroad, or from public or private research centers.
L'archive ouverte pluridisciplinaire HAL, est destinée au dépôt et à la diffusion de documents scientifiques de niveau recherche, publiés ou non, émanant des établissements d'enseignement et de recherche français ou étrangers, des laboratoires publics ou privés. 


\section{Intraadrenal Corticotropin in Bilateral Macronodular Adrenal Hyperplasia}

\author{
Estelle Louiset, Ph.D., Céline Duparc, Ph.D., Jacques Young, M.D., Ph.D., \\ Sylvie Renouf, Ph.D., Milène Tetsi Nomigni, M.Sc., Isabelle Boutelet, Ph.D., \\ Rossella Libé, M.D., Zakariae Bram, M.Sc., Lionel Groussin, M.D., Ph.D., \\ Philippe Caron, M.D., Antoine Tabarin, M.D., Ph.D., Fabienne Grunenberger, M.D., \\ Sophie Christin-Maitre, M.D., Ph.D., Xavier Bertagna, M.D., Ph.D., \\ Jean-Marc Kuhn, M.D., Youssef Anouar, Ph.D., \\ Jérôme Bertherat, M.D., Ph.D., and Hervé Lefebvre, M.D., Ph.D.
}

\section{BACKGROUND}

Bilateral macronodular adrenal hyperplasia is a rare cause of primary adrenal Cushing's syndrome. In this form of hyperplasia, hypersecretion of cortisol suppresses the release of corticotropin by pituitary corticotrophs, which results in low plasma corticotropin levels. Thus, the disease has been termed corticotropin-independent macronodular adrenal hyperplasia. We examined the abnormal production of corticotropin in these hyperplastic adrenal glands.

\section{METHODS}

We obtained specimens of hyperplastic macronodular adrenal tissue from $30 \mathrm{pa}-$ tients with primary adrenal disease. The corticotropin precursor proopiomelanocortin and corticotropin expression were assessed by means of a polymerase-chainreaction assay and immunohistochemical analysis. The production of corticotropin and cortisol was assessed in 11 specimens with the use of incubated explants and cell cultures coupled with hormone assays. Corticotropin levels were measured in adrenal and peripheral venous blood samples from 2 patients.

\section{RESULTS}

The expression of proopiomelanocortin messenger RNA (mRNA) was detected in all samples of hyperplastic adrenal tissue. Corticotropin was detected in steroidogenic cells arranged in clusters that were disseminated throughout the adrenal specimens. Adrenal corticotropin levels were higher in adrenal venous blood samples than in peripheral venous samples, a finding that was consistent with local production of the peptide within the hyperplastic adrenals. The release of adrenal corticotropin was stimulated by ligands of aberrant membrane receptors but not by corticotropinreleasing hormone or dexamethasone. A semiquantitative score for corticotropin immunostaining in the samples correlated with basal plasma cortisol levels. Corticotropin-receptor antagonists significantly inhibited in vitro cortisol secretion.

\section{CONCLUSIONS}

Cortisol secretion by the adrenals in patients with macronodular hyperplasia and Cushing's syndrome appears to be regulated by corticotropin, which is produced by a subpopulation of steroidogenic cells in the hyperplastic adrenals. Thus, the hypercortisolism associated with bilateral macronodular adrenal hyperplasia appears to be corticotropin-dependent. (Funded by the Agence Nationale de la Recherche and others.)
From INSERM Unité 982, Laboratory of Neuronal and Neuroendocrine Differentiation and Communication, Institute for Research and Innovation in Biomedicine, and Rouen University, Mont-Saint-Aignan (E.L., C.D., S.R., M.T.N., I.B., Z.B., J-.M.K., Y.A., H.L.), the Department of Endocrinology, Hôpital Bicêtre, Assistance PubliqueHôpitaux de Paris (AP-HP), University Paris Sud, INSERM Unité 693, Le Kremlin-Bicêtre (J.Y.), INSERM Unité 1016, Institut Cochin (R.L., L.G., X.B., J.B.), the Department of Endocrinology AP-HP, Hôpital Cochin (L.G., X.B., J.B.), Université Paris Descartes (L.G., X.B., J.B.), Centre National de la Recherche Scientifique Unité Mixte de Recherche 8104 (L.G., X.B., J.B.), and the Department of Endocrinology, Hôpital Saint-Antoine, AP-HP (S.C.-M.), Paris; the Department of Endocrinology and Metabolic Diseases, Centre Hospitalier Universitaire Larrey, Toulouse (P.C.); the Department of Endocrinology, Hôpital Haut Lévêque, Centre Hospitalier Universitaire de Bordeaux, Pessac (A.T.); Service de Médecine Interne et Nutrition, Centre Hospitalier Régional Universitaire de Strasbourg, Strasbourg (F.G.); and the Department of Endocrinology, Diabetes, and Metabolic Diseases, Rouen University Hospital, Rouen (J.M.K., H.L.) - all in France. Address reprint requests to Dr. Lefebvre at INSERM Unité 982, Department of Endocrinology, Institute for Research and Innovation in Biomedicine (IRIB), University Hospital of Rouen, 76031 Rouen CEDEX, France, or at herve.lefebvre@chu-rouen.fr.

N Engl J Med 2013;369:2115-25. DOI: 10.1056/NEJMoa1215245

Copyright ( 2013 Massachusetts Medical Society. 
HRONIC EXCESS OF GLUCOCORTICOIDS may lead to a constellation of symptoms that include central obesity and arterial hypertension, termed Cushing's syndrome, which is associated with increased mortality. In 10 to $20 \%$ of cases, Cushing's syndrome is caused by primary adrenal cortisol hypersecretion. ${ }^{1}$ Among patients with primary hypersecretion of adrenal cortisol, bilateral macronodular adrenal disease is extremely rare, representing less than $2 \%$ of all cases of Cushing's syndrome. Hypersecretion of cortisol by the enlarged adrenal glands suppresses the release of corticotropin by the anterior pituitary, leading to low plasma levels of corticotropin. For this reason, the disease has also been called corticotropin-independent macronodular adrenal hyperplasia.

An understanding of the pathophysiology of corticotropin-independent macronodular adrenal hyperplasia has long been elusive. The persistence of cortisol hypersecretion despite suppressed plasma corticotropin levels was considered to be the result of an autonomous process. However, several studies published over the past two decades have shown that hyperplastic adrenal glands display abnormal expression of various membrane receptors that are involved in the control of cortisol production. ${ }^{2-6}$ These aberrant receptors include ectopic receptors for glucose-dependent insulinotropic peptide, luteinizing hormone, and catecholamines and abnormally active eutopic receptors such as the vasopressin type $1 \mathrm{a}^{5}$ and serotonin type 4 receptors. ${ }^{7-10}$ The molecular defects that have been characterized in samples of hyperplastic adrenals also include activating mutations in the genes that encode the corticotropin receptor, ${ }^{11} \mathrm{G}$-protein subunit $\alpha_{\mathrm{s}}{ }^{12}$ and phosphodiesterase $11 \mathrm{~A},{ }^{13}$ as well as the aberrant expression of bioactive signals in the adrenocortical cells, which leads to the formation of intraadrenal regulatory loops. ${ }^{7}$

We previously described aberrant expression of corticotropin in a single case of corticotropinindependent macronodular adrenal hyperplasia, ${ }^{14}$ which suggests that ectopic production of the peptide in the adrenal cortex may have induced adrenocortical hyperplasia and hypercortisolism. There were subsequent reports of two additional cases of macronodular adrenal hyperplasia associated with ectopic localization of corticotropin in adrenocortical cells. ${ }^{15,16}$ The ectopic production of corticotropin by adrenocortical cells has also been observed in an adrenocortical-pituitary hybrid tumor causing Cushing's syndrome. ${ }^{17}$ In the present study, we examined corticotropin production in adrenal glands from a series of patients with macronodular adrenal hyperplasia and decreased levels of peripheral corticotropin.

METHODS

\section{DIAGNOSIS OF CUSHING'S SYNDROME}

We studied 30 patients with macronodular adrenal hyperplasia associated with subclinical or overt Cushing's syndrome (Table S1 in the Supplementary Appendix, available with the full text of this article at NEJM.org); 2 patients had familial disease (Patients 18 and 19), and 28 had sporadic disease. The diagnosis of primary adrenal Cushing's syndrome was based on standard biologic criteria, including an increase in 24-hour urinary cortisol excretion; abolition of the relationship between the circadian rhythm and levels of plasma cortisol; lack of cortisol suppression after the administration of dexamethasone (Table S2 in the Supplementary Appendix); and decreased basal levels of plasma corticotropin $(<10 \mathrm{ng}$ per liter [2.2 nmol per liter]). The diagnosis of subclinical Cushing's syndrome was established on the basis of an abnormal cortisol response to the administration of $1 \mathrm{mg}$ of dexamethasone (cortisol level, $>18 \mu$ g per liter [50 nmol per liter]). We also searched for potentially aberrant membrane receptors, as previously reported. ${ }^{7}$

\section{SPECIMEN COLLECTION AND CORTICOTROPIN MEASUREMENT}

Specimens of hyperplastic macronodular adrenal tissue were collected at surgery from 13 patients (prospective study, Patients 1 through 13) and were processed for subsequent in vitro experiments. For the remaining 17 patients (retrospective study, Patients 14 through 30), immunohistochemical or molecular studies were performed on fixed and frozen samples. Control specimens included fragments of seven normal adrenals obtained from patients undergoing expanded nephrectomy for kidney cancer and from four cortisol-producing adenomas. Plasma corticotropin levels were measured in samples of right and left adrenal and peripheral venous blood from Patients 12 and 13 (three samples were obtained from each site in each patient). The same procedure was followed for the 5 control patients with aldosterone-producing adenomas. We used a solidphase, two-site sequential chemiluminescence 
immunometric assay (Siemens Healthcare Diagnostics Products) with a lower limit of detection of $2 \mathrm{ng}$ per liter $(0.44 \mathrm{nmol}$ per liter). The results are expressed as means \pm SE.

\section{IN VITRO STUDIES}

Synthesis and secretion of corticotropin in the hyperplastic adrenal glands were investigated with the use of reverse-transcriptase-polymerase-chainreaction (RT-PCR) assays and immunohistochemical analyses and by means of cell-culture experiments and incubated adrenal explants. Genetic studies were performed to search for mutations of PDE11A (encoding phosphodiesterase 11A) and GNAS (encoding G-protein subunit $\alpha_{\mathrm{S}}$ ). ${ }^{12}$ Details of the methods used for these studies are provided in the Material and Methods section and Tables S3 through S6 in the Supplementary Appendix.

\section{STUDY OVERSIGHT}

The protocols for the collection of adrenal samples and the experimental procedures were approved by the regional ethics committees. Written informed consent was obtained from all patients. The authors vouch for the accuracy and completeness of the data.

\section{RESULTS}

\section{PATIENTS}

The 30 patients ranged in age from 34 to 76 years; 21 had overt Cushing's syndrome (Table 1). Clinical and biologic characteristics of the patients are summarized in Tables S1 and S2 in the Supplementary Appendix. No patient had a history of cancer.

\section{CORTICOTROPIN EXPRESSION}

Messenger RNA (mRNA) encoding the corticotropin precursor proopiomelanocortin was detected in all 26 hyperplastic adrenal samples tested by means of conventional and real-time RT-PCR. Values ranged from 4.2 to $62.6 \mathrm{pg}$ of proopiomelanocortin mRNA per $1 \mathrm{ng}$ of cyclophilin mRNA (median, 32.5) (Fig. 1A).

Immunohistochemical analysis of hyperplastic adrenal samples from 25 patients with anticorticotropin antibodies revealed the presence of immunoreactive cells in the subcapsular region of the adrenals, the hyperplastic macronodules, or both (Fig. S1A in the Supplementary Appendix). Isolated corticotropin-positive cells were observed in only 4 of the 25 available samples (16\%); in the other 21 samples (84\%), they were arranged in clusters. Corticotropin immunoreactivity was detected in the two subpopulations of cells in hyperplastic samples - spongiocytes, which were characterized by abundant cytoplasm and lipid droplets, and small compact cells (Fig. 1B). Semiquantitative evaluation of immunolabeling of the spongiocytes and compact cells showed moderate immunostaining (in 9 samples [36\%] and 8 samples [32\%], respectively) or intense immunostaining (in 11 samples [44\%] and 14 samples [56\%], respectively). The immunostaining was focal for spongiocytes in 18 samples (72\%) and for compact cells in 17 samples (68\%) (Fig. S1B and S1C in the Supplementary Appendix). Corticotropinimmunopositive cells were also labeled by antibodies against prohormone convertase 1 (in all 14 available samples), a peptidase known to cleave the precursor protein proopiomelanocortin into active corticotropin, and by antibodies against the granule-specific protein secretogranin II (in all 10 available samples) (Fig. S2 in the Supplementary Appendix). No corticotropin immunostaining was detected in the cortex of six normal adrenal glands or in four cortisol-secreting adenomas (Fig. S3 in the Supplementary Appendix).

Adrenocortical cells that were immunopositive for corticotropin were negative for the chromaffin tissue marker chromogranin A (in all 6 samples studied) (Fig. 2A and 2B); CD45, which allows labeling of leukocytes (in all 4 samples studied) (Fig. 2C and 2D); and HLA-DR (in all 5 samples studied) (Fig. S4 and S5 in the Supplementary Appendix). Staining of sections of hyperplastic adrenal tissue with antibodies to T-box factor, pituitary (TPIT), a transcription factor specifically involved in the differentiation of the corticotroph pituitary lineage,,$^{20,21}$ produced no signal in 5 of 7 samples examined (Fig. 2E and 2F). There was weak immunostaining in the cytoplasm of corticotropin-positive cells in 2 samples and in some cell cords of the normal adrenal cortex (Fig. S6 in the Supplementary Appendix). The expression levels of TPIT mRNA were similar in the samples of normal and macronodular hyperplastic adrenal tissue but appeared to be much lower than the expression levels in a sample from a corticotropic adenoma of the pituitary. Corticotropin-positive cells were stained intensely by antibodies against markers of steroidogenic differentiation, including steroidogenic factor 1 (in all 5 available samples); scavenger receptor class B type I, the high-density lipoprotein receptor (in all 14 available samples); 


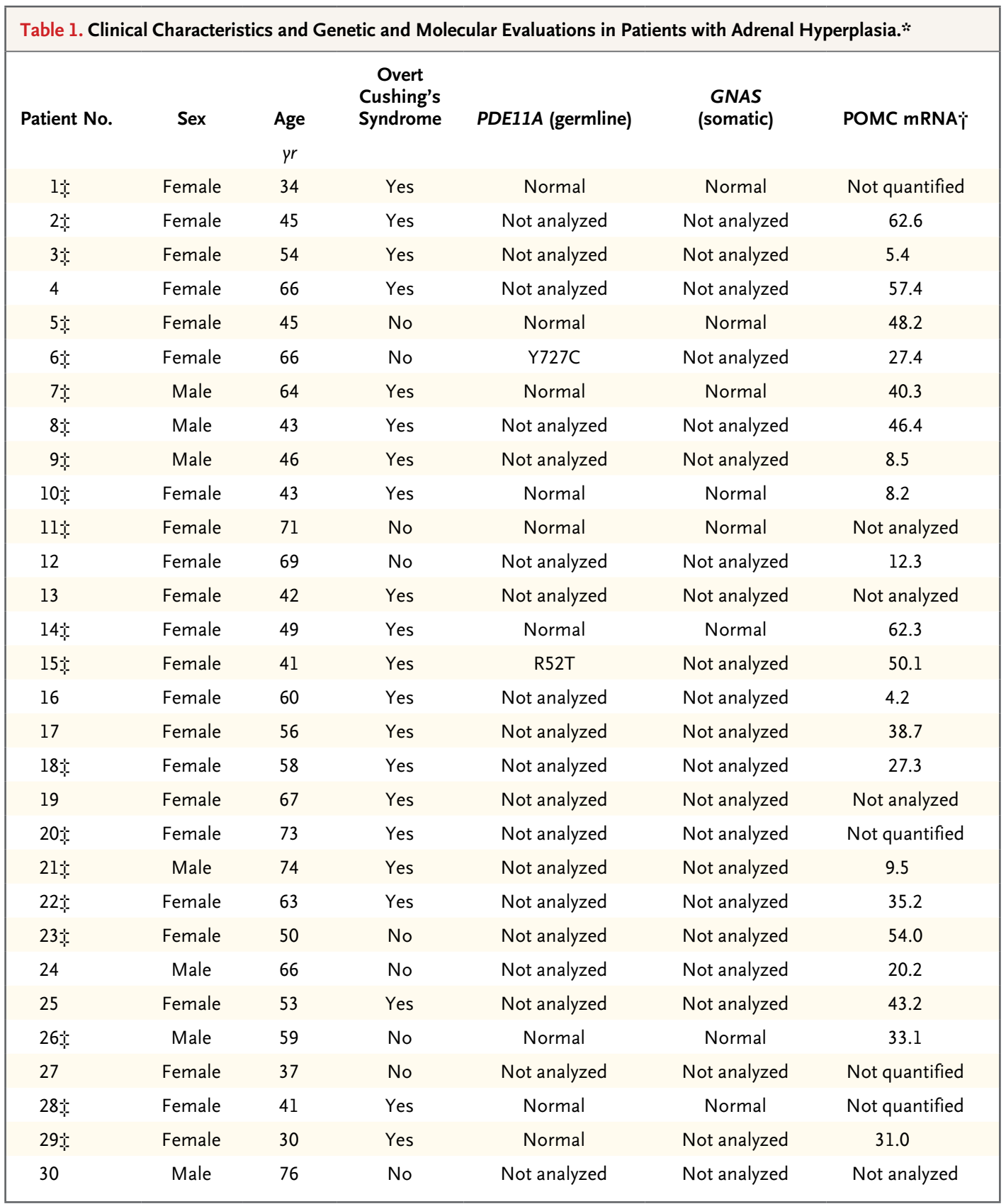

* PDE11A denotes the gene encoding phosphodiesterase 11A, and GNAS the gene encoding the G-protein subunit $\alpha_{\mathrm{S}}(\mathrm{GS} \alpha)$. $\uparrow$ Messenger RNA (mRNA) expression levels for POMC, the gene encoding proopiomelanocortin, which were measured with the use of real-time reverse-transcriptase-polymerase-chain-reaction assays, have been expressed as picograms per nanogram of cyclophilin.

$\left\lceil\right.$ Data have previously been reported for 20 of the patients, as follows: Patient $1^{7-9,18}$; Patients 2 and $3^{7,8}$; Patients 5, 6, and $7^{18}$; Patient $8^{10}$; Patient $9^{9,14}$; Patient 1013; Patient $11^{18}$; Patient 147,18; Patient $15^{13}$; Patient $18^{19}$; Patients 20 through $23^{9}$; Patients 26 and $28^{18}$; and Patient $29 .{ }^{13}$

and the key steroidogenic enzyme $17 \alpha$-hydroxylase 3 (in all 8 available samples) (Fig. S7 in the Supple(in all 14 available samples) (Fig. 2G through 2L). mentary Appendix). Conversely, insulin-like 3 imCorticotropin-synthesizing cells were also immu- munoreactivity was not detected in samples of nopositive for the Leydig cell marker insulin-like normal adrenal cortex tissue. 


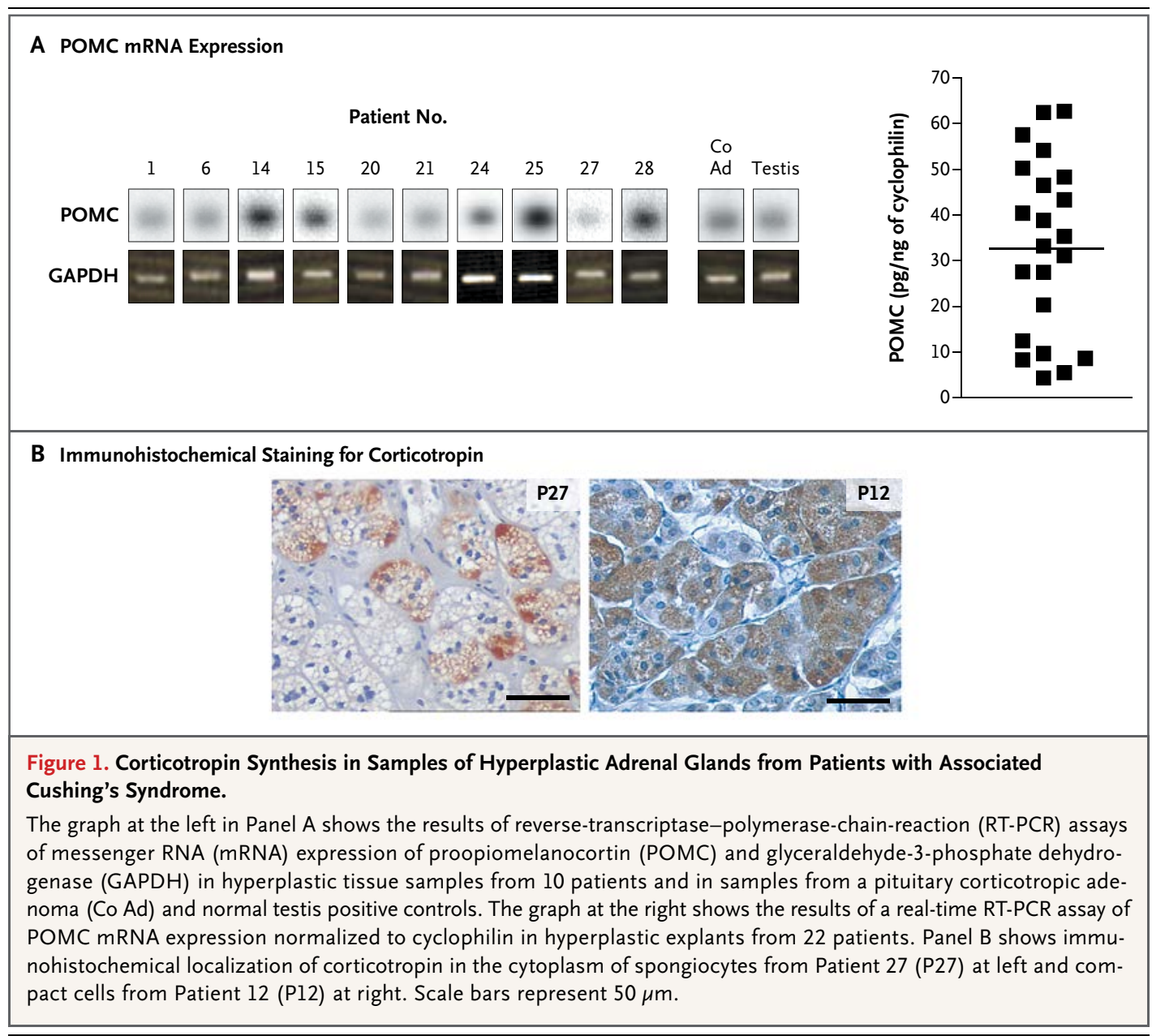

\section{CORTICOTROPIN SECRETION}

In two patients with adrenocortical hyperplasia (Patients 12 and 13), plasma corticotropin levels in the right and left adrenal veins were higher than those in the peripheral veins $(26.6 \pm 5.5$ and $15.0 \pm 2.0$ pg per milliliter $[5.9 \pm 1.2$ and $3.3 \pm 0.4$ pmol per liter], respectively, vs. $2.0 \pm 0.5 \mathrm{pg}$ per milliliter [0.4 \pm 0.1 pmol per liter] in Patient 12, and 54.0 \pm 3.6 and $36.0 \pm 3.0 \mathrm{pg}$ per milliliter [11.9 \pm 0.8 and $7.9 \pm 0.7$ pmol per liter], respectively, vs. $4.6 \pm 1.2 \mathrm{pg}$ per milliliter [1.0 \pm 0.3 pmol per liter] in Patient 13). However, in patients with an aldosterone-producing adenoma, plasma corticotropin levels were similar in the adrenal and peripheral veins (Fig. 3A).

In vitro incubation studies revealed that all adrenocortical hyperplasia explants spontaneously released corticotropin in a pulsatile fashion, with a frequency of $3.85 \pm 0.23$ pulses per hour (Fig. 3B). Cortisol production was significantly correlated with corticotropin release in 7 of
11 explants (64\%). Conditioned medium removed after the incubation of explants from Patients 4, $5,7,10$, and 11 stimulated corticosterone secretion in samples of cultured adrenocortical cells from rats. After subtraction of the concentrations of corticosterone in the added medium, the net steroidogenic responses of the cells were positively correlated with the measured corticotropin levels produced by the explants (Fig. S8A in the Supplementary Appendix). Corticostatin, a corticotropin-receptor antagonist, inhibited the stimulatory action of conditioned medium on the cultured rat cells (Fig. S8B in the Supplementary Appendix). Both spontaneous cortisol secretion and corticotropin-induced cortisol secretion by hyperplastic explants were reduced by the two melanocortin 2 receptor (MC2R) antagonists corticostatin and corticotropin(7-38), the corticotropin fragment corresponding to amino acids 7 to 38 of the peptide (Fig. 3C and 4B, and Table S7 


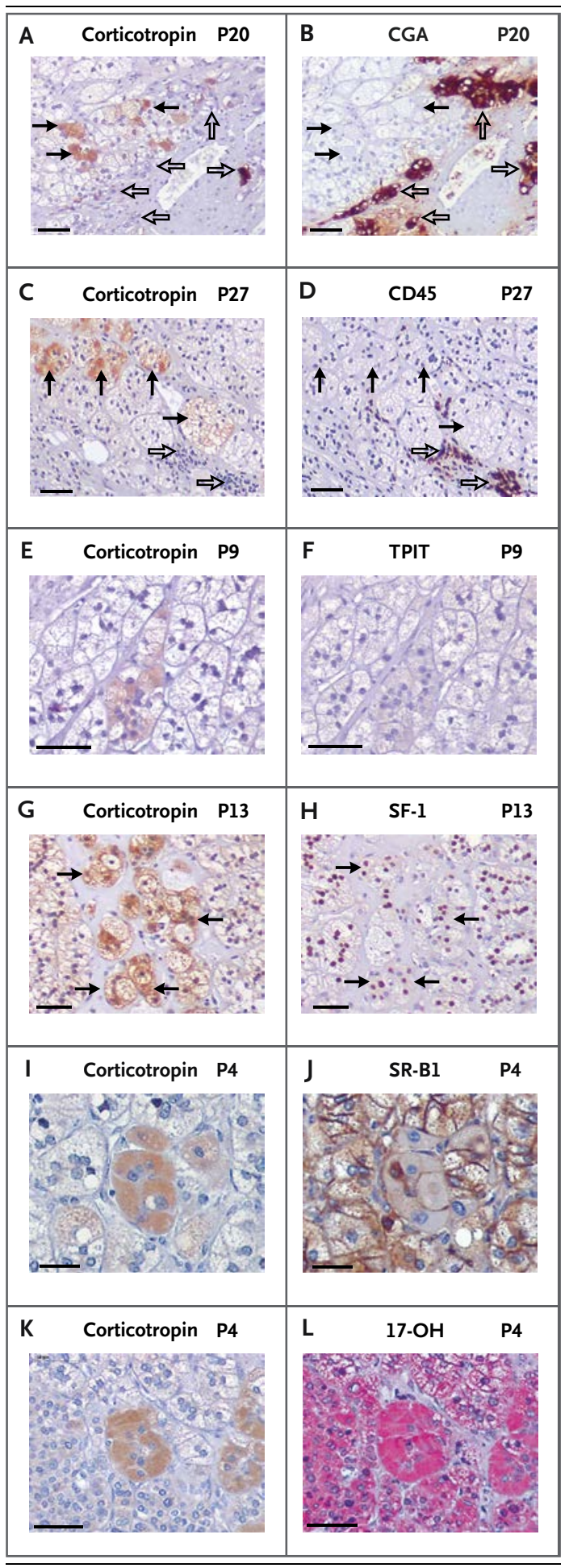

in the Supplementary Appendix). In addition, basal cortisol levels correlated positively with both the histologic corticotropin intensity scores (Fig. 3D) and MC2R mRNA expression levels (Fig. $3 E$ ) in the hyperplastic samples studied. (MC2R
Figure 2. Immunohistologic Characterization of Corticotropin-Producing Cells in Hyperplastic Adrenal Samples from Patients with Associated Cushing's Syndrome.

Immunohistochemical labeling of consecutive sections of hyperplastic tissue reveals antibodies against corticotropin (Panels A, C, E, G, I, and K), chromogranin A (CGA) (Panel B), CD45 (Panel D), and T-box factor, pituitary (TPIT) (Panel F), as well as antibodies against markers of steroidogenic differentiation, including steroidogenic factor 1 (SF-1) (Panel H), scavenger-receptor class B type 1 (SR-Bl) (Panel J), and $17 \alpha$-hydroxylase $(17-\mathrm{OH})($ Panel L). Black arrows denote cells that are positive for corticotropin, and open arrows cells that are positive for CGA (Panel B) or CD45 (Panel D). Immunostaining was revealed with the use of diaminobenzidine (brown) or permanent red (pink). Patient numbers are indicated as $\mathrm{Pl}, \mathrm{P} 2$, and so on. Scale bars represent $50 \mu \mathrm{m}$.

mRNA and steroidogenic enzyme mRNA expression levels are shown in the Results section and in Fig. S9 and S10, respectively, in the Supplementary Appendix.)

When hyperplastic explants from patients with abnormal plasma cortisol responses to glucose-dependent insulinotropic peptide, serotonin, and human chorionic gonadotropin were incubated with these same compounds, corticotropin secretion increased. Similarly, these compounds provoked a marked and prolonged increase in cortisol release (Fig. 4A, and Table S7 and Fig. S11 in the Supplementary Appendix). The effect of glucose-dependent insulinotropic peptide on cortisol secretion was significantly reduced in the presence of the MC2R antagonist corticotropin(7-38) (Fig. 4B). Corticotropinreleasing hormone $\left(10^{-7} \mathrm{M}\right)$, dexamethasone $\left(10^{-6} \mathrm{M}\right)$, and the glucocorticoid receptor antagonist mifepristone $\left(10^{-6} \mathrm{M}\right)$ had no significant effect on the secretion of corticotropin by hyperplastic explants (data not shown).

\section{GENETIC STUDIES}

We searched for somatic mutations of GNAS. No mutations were found (Table 1).

\section{DISCUSSION}

We sought to detect abnormal expression of corticotropin in a series of patients with Cushing's syndrome and what has been called "corticotropinindependent" bilateral macronodular adrenal hyperplasia. The mRNA encoding the corticotropin precursor proopiomelanocortin was detected in all hyperplastic adrenal samples studied. In addition, 


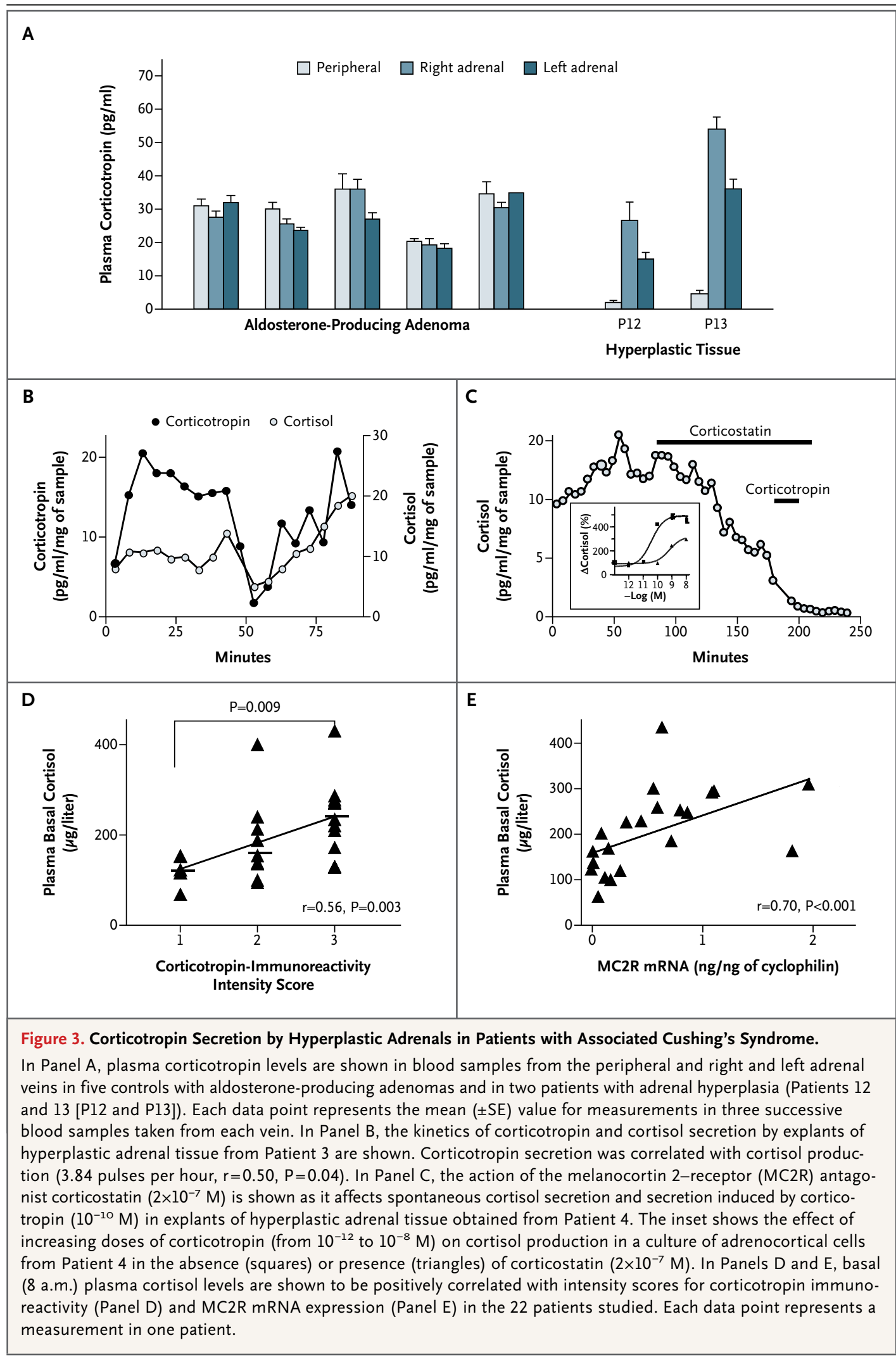

N ENGLJ MED 369;22 NEJM.ORG NOVEMBER 28, 2013

The New England Journal of Medicine

Downloaded from nejm.org at INSERM DISC DOC on November 28, 2013. For personal use only. No other uses without permission. 

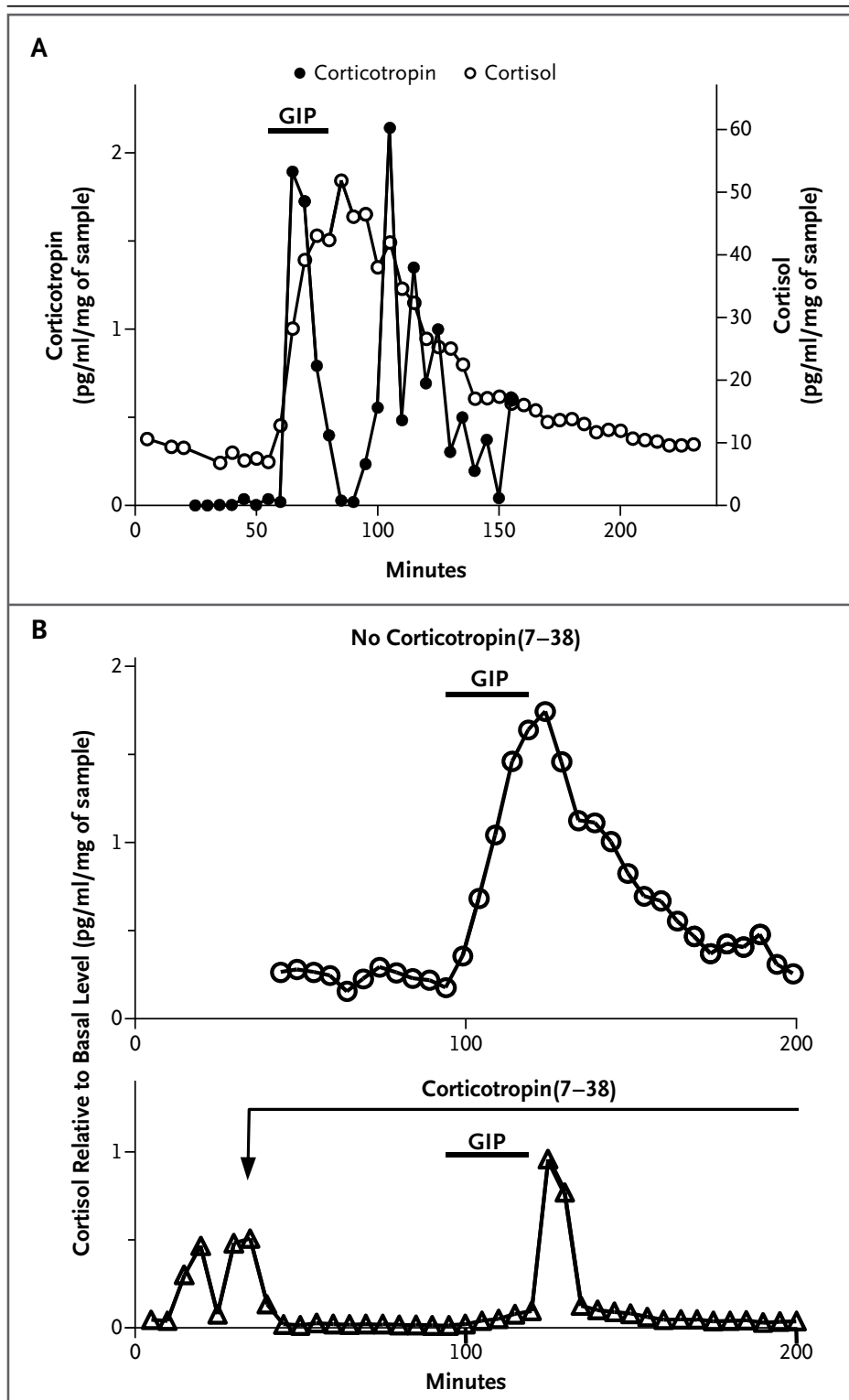

Figure 4. Regulation of Corticotropin Production by Glucose-Dependent Insulinotropic Peptide.

Panel A shows the effect of $10^{-7} \mathrm{M}$ glucose-dependent insulinotropic peptide (GIP) on corticotropin and cortisol secretion by explants of hyperplastic adrenal tissue obtained from Patient 10. Panel $B$ shows the effect of $10^{-7} \mathrm{M}$ GIP on cortisol secretion in the absence (top graph) and presence (bottom graph) of $10^{-7} \mathrm{M}$ corticotropin fragment(7-38) by explants of hyperplastic adrenal tissue obtained from Patient 10. Corticotropin fragment(7-38) significantly reduced the cortisol response to GIP $(P<0.05)$. Corticotropin fragment(7-38) consists of amino acids 7 to 38 of the peptide. hyperplastic specimens expressed prohormone convertase type 1 , which suggests that adrenals affected by macronodular adrenal hyperplasia may generate bioactive corticotropin after pro- cessing its precursor. Immunohistochemical studies confirmed the presence of corticotropin in adrenocortical cells that were distributed heterogeneously throughout the specimens, a finding that is consistent with the marked variability in levels of proopiomelanocortin mRNA expression.

Several cell types (e.g., chromaffin cells, lymphocytes, and pituitary corticotrophs) have been reported to produce corticotropin. ${ }^{22,23}$ We examined the phenotype of corticotropin-positive cells by means of immunohistochemical analysis, using antibodies against markers for these various cell types. We observed that corticotropin expression in the hyperplastic adrenal samples did not result from adrenal chromaffin-like, lymphocyte-like, or pituitary corticotroph-like cell differentiation. The corticotropin-containing cells exhibited the morphologic characteristics of steroidogenic cells and were also consistently labeled by antibodies to steroidogenic factor 1 , a transcription factor that triggers steroidogenic differentiation ${ }^{24}$; the receptor for the high-density lipoprotein scavenger receptor class B type 1 , which plays an important role in maintaining the supply of cholesterol for adrenal steroidogenesis ${ }^{25}$; and $17 \alpha$-hydroxylase, a key enzyme in the synthesis of cortisol and androgens.

Major-histocompatibility-complex class II antigens, which are normally expressed in the inner layer of the adrenal cortex, ${ }^{26}$ were not expressed by the corticotropin-positive cells. Conversely, the expression of insulin-like $3,{ }^{27}$ a marker of Leydig and luteal cells, by corticotropinpositive cells, together with the well-demonstrated occurrence of corticotropin in steroid-producing gonadal cells, ${ }^{28,29}$ suggests that abnormal synthesis of corticotropin may be a trait of gonadallike differentiation. Because adrenocortical and gonadal stem cells both derive from the mesonephros, we speculate that the presence of gonadal-like cells in the adrenal glands may result from the abnormal differentiation of certain steroidogeniccell progenitors or from the defective migration of some gonadal stem cells during embryogenesis. This pathologic process may represent the counterpart of the presence of adrenal rests in the gonads, a phenomenon that has been well documented in the testis. ${ }^{30}$

The molecular defect that causes macronodular adrenal hyperplasia may be complex, and the disease is a heterogeneous disorder that can be associated with various genetic defects at germline or somatic levels. ${ }^{12,13,31}$ In the present study, 
two patients had previously been shown to carry germline mutations in PDE11A, a gene associated with macronodular adrenal hyperplasia. ${ }^{13,18}$ Since all the hyperplastic adrenal specimens examined contained corticotropin-positive cells, we speculate that the abnormal expression of corticotropin by some adrenocortical cells may represent a secondary pathophysiological process that is common to diverse molecular defects and is seen in both sporadic and familial cases.

The presence of corticotropin in cytoplasmic granules and its association with secretogranin II immunoreactivity suggest that corticotropin may be released within the adrenal cortex through exocytosis. Our in vitro results show that corticotropin can be secreted by hyperplastic explants. The release of corticotropin by the adrenal glands was also observed in vivo in two patients, both of whom had higher plasma levels of corticotropin in the adrenal veins than in the peripheral veins. Thus, it is conceivable that in some patients with macronodular hyperplasia and markedly elevated cortisol levels, ${ }^{32}$ detectable plasma corticotropin levels are due to ectopic production of the peptide by the hyperplastic glands. A case report by Hiroi et al. ${ }^{17}$ about a patient with an adrenocortical-pituitary hybrid adenoma and paradoxically normal plasma corticotropin levels supports this idea. In that patient, adrenal corticotropin production was detected on adrenal-vein catheterization, and surgical removal of the neoplasm suppressed corticotropin levels.

Our results also suggest that in patients with macronodular adrenal hyperplasia, overt hypercorticolism, and unsuppressed plasma corticotropin levels, corticotropin secretion by the adrenal glands should be considered and explored by sampling the adrenal veins rather than by catheterizing the inferior petrosal sinus. ${ }^{17}$ Our observation that adrenocortical explants released corticotropin, together with cortisol, in a pulsatile fashion is consistent with a study showing that cortisol production is pulsatile in patients with Cushing's syndrome due to bilateral macronodular adrenal hyperplasia ${ }^{33}$ and with previous observations showing a relationship between intraadrenal oscillators and the expression of "clock genes." ${ }^{34}$

Our observation that cortisol levels correlated positively with corticotropin levels in conditioned medium from adrenal explants raises the possibility that corticotropin, when produced by some steroidogenic cells, may stimulate cortisol secre- tion through a paracrine mechanism. This hypothesis is supported by our in vitro findings: conditioned medium from hyperplastic adrenal explants stimulated the production of corticosterone in cultured rat adrenocortical cells, an effect that was inhibited by an MC2R-receptor antagonist, indicating that intraadrenal corticotropin is actually bioactive; corticotropin-receptor antagonists reduced the production of cortisol in hyperplastic explants. In addition, basal plasma cortisol levels correlated positively with both the histologic corticotropin scores and MC2R expression levels in hyperplastic adrenal samples. These results suggest that in macronodular adrenal hyperplasia, intraadrenal corticotropin plays an important role in the regulation of cortisol secretion. We speculate that the recently developed corticotropin-receptor antagonists might provide an alternative treatment for hypercortisolism associated with adrenal macronodular hyperplasia. Ectopic synthesis of corticotropin by adrenocortical cells may also be involved in the development of hyperplasia through the angiogenic and antiapoptotic actions of the peptide on the adrenocortical tissue. ${ }^{35}$

When we examined the effect of classic regulators of pituitary corticotropin secretion on the release of corticotropin by hyperplastic explants, we found that corticotropin-releasing hormone had no substantial action. Similarly, dexamethasone and the glucocorticoid-receptor antagonist mifepristone did not affect the release of corticotropin, indicating that cortisol is not involved in a feedback mechanism that inhibits the production of corticotropin in adrenal hyperplastic tissues. Conversely, we observed that corticotropin production was stimulated by regulatory factors that activate aberrant membrane receptors expressed by hyperplastic tissues (i.e., glucose-dependent insulinotropic peptide, serotonin, and human chorionic gonadotropin) (see the Discussion section in the Supplementary Appendix).

In conclusion, the present study shows that in patients with bilateral macronodular adrenal hyperplasia and Cushing's syndrome, cortisol production is controlled both by aberrant membrane receptors and by corticotropin that is produced within the adrenocortical tissue, which appears to act as a local amplifier of the action of these receptors. From a pathophysiological point of view, the term "corticotropin-independent," which has been used to designate cases of bilateral ad- 
renal macronodular hyperplasia with hypercortisolism and low plasma corticotropin levels, appears to be inappropriate. The disease instead seems to be a cause of primary adrenal Cushing's syndrome in association with the ectopic expression of corticotropin within the adrenal cortex. Thus, the term "bilateral macronodular adrenal hyperplasia" would seem to be a better and more accurate description of the disease. ${ }^{36}$
Supported by grants from INSERM Unité 982, Agence Nationale de la Recherche (Programme blanc 2010, GePAH project), Centre Hospitalier Universitaire de Rouen, Réseau COMETE, Assistance Publique-Hôpitaux de Paris, and Conseil Régional de Haute-Normandie.

Disclosure forms provided by the authors are available with the full text of this article at NEJM.org.

We thank Drs. Françoise Gobet, Gaëlle Barrande, Yves Reznik, Frederique Tissier, and Patricia Vergani for their collaboration; Dr. Jacques Drouin for his gift of anti-TPIT antibodies; and Huguette Lemonnier, Arnaud Arabo, and Fernande René-Corail for their technical assistance.

\section{REFERENCES}

1. Newell-Price J, Bertagna X, Grossman $A B$, Nieman LK. Cushing's syndrome. Lancet 2006;367:1605-17.

2. Lacroix A, Tremblay J, Rousseau G, Bouvier M, Hamet P. Propranolol therapy for ectopic beta-adrenergic receptors in adrenal Cushing's syndrome. N Engl J Med 1997;337:1429-34.

3. Reznik Y, Allali-Zerah V, Chayvialle JA, et al. Food-dependent Cushing's syndrome mediated by aberrant adrenal sensitivity to gastric inhibitory polypeptide. N Engl J Med 1992;327:981-6.

4. Lacroix A, Bolté E, Tremblay J, et al. Gastric inhibitory polypeptide-dependent cortisol hypersecretion - a new cause of Cushing's syndrome. N Engl J Med 1992; 327:974-80.

5. Mune T, Murase H, Yamakita N, et al. Eutopic overexpression of vasopressin v1a receptor in adrenocorticotropin-independent macronodular adrenal hyperplasia. J Clin Endocrinol Metab 2002;87:5706-13. 6. De Groot JWB, Links TP, Themmen APN, et al. Aberrant expression of multiple hormone receptors in ACTH-independent macronodular adrenal hyperplasia causing Cushing's syndrome. Eur J Endocrinol 2010; 163:293-9.

7. Bertherat J, Contesse V, Louiset E, et al. In vivo and in vitro screening for illegitimate receptors in adrenocorticotropin-independent macronodular adrenal hyperplasia causing Cushing's syndrome: identification of two cases of gonadotropin/ gastric inhibitory polypeptide-dependent hypercortisolism. J Clin Endocrinol Metab 2005;90:1302-10.

8. Louiset E, Contesse V, Groussin L, et al. Expression of serotonin7 receptor and coupling of ectopic receptors to protein kinase $\mathrm{A}$ and ionic currents in adrenocorticotropin-independent macronodular adrenal hyperplasia causing Cushing's syndrome. J Clin Endocrinol Metab 2006;91: 4578-86.

9. Cartier D, Lihrmann I, Parmentier F, et al. Overexpression of serotonin 4 receptors in cisapride-responsive adrenocorticotropin-independent bilateral macronodular adrenal hyperplasia causing Cushing's syndrome. J Clin Endocrinol Metab 2003;88:248-54.
10. Assie G, Louiset E, Sturm N, et al. Systematic analysis of $\mathrm{G}$ protein-coupled receptor gene expression in adrenocorticotropin-independent macronodular adrenocortical hyperplasia identifies novel targets for pharmacological control of adrenal Cushing's syndrome. J Clin Endocrinol Metab 2010;95:E253-E262.

11. Swords FM, Baig A, Malchoff DM, et al. Impaired desensitization of a mutan adrenocorticotropin receptor associated with apparent constitutive activity. Mol Endocrinol 2002;16:2746-53.

12. Fragoso MC, Domenice S, Latronico $\mathrm{AC}$, et al. Cushing's syndrome secondary to adrenocorticotropin-independent macronodular adrenocortical hyperplasia due to activating mutations of GNAS1 gene. J Clin Endocrinol Metab 2003;88:2147-51.

13. Vezzosi D, Libé R, Baudry $C$, et al Phosphodiesterase 11A (PDE11A) gene defects in patients with ACTH-independent macronodular adrenal hyperplasia (AIMAH): functional variants may contribute to genetic susceptibility of bilateral adrenal tumors. J Clin Endocrino Metab 2012;97:E2063-E2069.

14. Lefebvre H, Duparc C, Chartrel N, et al Intraadrenal adrenocorticotropin production in a case of bilateral macronodular adrenal hyperplasia causing Cushing's syndrome. J Clin Endocrinol Metab 2003;88 3035-42.

15. Mazzuco TL, Thomas M, Martinie M et al. Cellular and molecular abnormalities of a macronodular adrenal hyperplasia causing beta-blocker-sensitive Cushing's syndrome. Arq Bras Endocrinol Metabol 2007;51:1452-62.

16. Iwata $M$, Oki $Y$, Okazawa $T$, et al A rare case of adrenocorticotropic hormone (ACTH)-independent macroadrena hyperplasia showing ectopic production of ACTH. Intern Med 2012;51:2181-7.

17. Hiroi N, Chrousos GP, Kohn B, et al. Adrenocortical-pituitary hybrid tumor causing Cushing's syndrome. J Clin Endocrinol Metab 2001;86:2631-7.

18. Libé R, Fratticci A, Coste J, et al. Phosphodiesterase 11A (PDE11A) and genetic predisposition to adrenocortical tumors. Clin Cancer Res 2008;14:4016-24.

19. Vezzosi D, Cartier D, Régnier C, et al.
Familial adrenocorticotropin-independent macronodular adrenal hyperplasia with aberrant serotonin and vasopressin adrenal receptors. Eur J Endocrinol 2007;156:21-31. 20. Lamolet B, Pulichino AM, Lamonerie $\mathrm{T}$, et al. A pituitary cell-restricted $\mathrm{T}$ box factor, Tpit, activates POMC transcription in cooperation with Pitx homeoproteins. Cell 2001;104:849-59.

21. Vallette-Kasic S, Figarella-Branger D, Grino $M$, et al. Differential regulation of proopiomelanocortin and pituitaryrestricted transcription factor (TPIT), a new marker of normal and adenomatous human corticotrophs. J Clin Endocrinol Metab 2003;88:3050-6.

22. Suda $\mathrm{T}$, Tomori $\mathrm{N}$, Tozawa $\mathrm{F}$, et al. Immunoreactive corticotropin and corticotropin-releasing factor in human hypothalamus, adrenal, lung cancer, and pheochromocytoma. J Clin Endocrinol Metab 1984;58:919-24.

23. Meyer WJ III, Smith EM, Richards GE, Cavallo A, Morrill AC, Blalock JE. In vivo immunoreactive adrenocorticotropin (ACTH) production by human mononuclear leukocytes from normal and ACTH-deficient individuals. J Clin Endocrinol Metab 1987;64:98-105.

24. Parker KL, Schimmer BP. Steroidogenic factor 1: a key determinant of endocrine development and function. Endocr Rev 1997;18:361-77.

25. Connelly MA. SR-BI-mediated HDL cholesteryl ester delivery in the adrenal gland. Mol Cell Endocrinol 2009;300:83-8. 26. Marx C, Bornstein SR, Wolkersdörfer GW, Peter M, Sippell WG, Scherbaum WA. Relevance of major histocompatibility complex class II expression as a hallmark for the cellular differentiation in the human adrenal cortex. J Clin Endocrinol Metab 1997;82:3136-40.

27. Ivell $R$, Balvers $M$, Domagalski R, Ungefroren $\mathrm{H}$, Hunt N, Schulze W. Relaxin-like factor: a highly specific and constitutive new marker for Leydig cells in the human testis. Mol Hum Reprod 1997;3:459-66.

28. de Keyzer Y, Lenne F, Massias JF, et al. Pituitary-like proopiomelanocortin transcripts in human Leydig cell tumors. J Clin Invest 1990;86:871-7.

29. Lacaze-Masmonteil T, de Keyzer Y, 
Luton JP, Kahn A, Bertagna X. Characterization of proopiomelanocortin transcripts in human nonpituitary tissues. Proc Natl Acad Sci U S A 1987;84:7261-5.

30. Claahsen-van der Grinten HL, Hermus ARMM, Otten BJ. Testicular adrenal rest tumours in congenital adrenal hyperplasia Int J Pediatr Endocrinol 2009;23:209-20.

31. Hsiao H-P, Kirschner LS, Bourdeau I, et al. Clinical and genetic heterogeneity, overlap with other tumor syndromes, and atypical glucocorticoid hormone secretion in adrenocorticotropin-independent macronodular adrenal hyperplasia com- pared with other adrenocortical tumors. J Clin Endocrinol Metab 2009;94:2930-7.

32. Swain JM, Grant CS, Schlinkert RT, et al. Corticotropin-independent macronodular adrenal hyperplasia: a clinicopathologic correlation. Arch Surg 1998;133:541-5. 33. van Aken MO, Pereira AM, Van Thiel $\mathrm{SW}$, et al. Irregular and frequent cortisol secretory episodes with preserved diurnal rhythmicity in primary adrenal Cushing's syndrome. J Clin Endocrinol Metab 2005; 90:1570-7.

34. Kalsbeek A, van der Spek R, Lei J, Endert E, Buijs RM, Fliers E. Circadian rhythms in the hypothalamo-pituitaryadrenal (HPA) axis. Mol Cell Endocrinol 2012;349:20-9.

35. Thomas M, Keramidas M, Monchaux E, Feige J-J. Dual hormonal regulation of endocrine tissue mass and vasculature by adrenocorticotropin in the adrenal cortex. Endocrinology 2004;145:4320-9.

36. Stratakis CA, Boikos SA. Genetics of adrenal tumors associated with Cushing's syndrome: a new classification for bilateral adrenocortical hyperplasias. Nat Clin Pract Endocrinol Metab 2007;3:748-57.

Copyright (c) 2013 Massachusetts Medical Society. of Medical Journal Editors (ICMJE) will consider most reports of clinical trials for publication only if the trials have been registered.

Current information on requirements and appropriate registries is available at www.icmje.org/faq_clinical.html.

The New England Journal of Medicine 